\title{
PENGARUH SISTEM AKUNTANSI MANAJEMEN TERHADAP KINERJA MANAJERIAL PADA PT. MARAJASA
}

\author{
Desy Astrid Anindya \\ Fakultas Ekonomi, Universitas Medan Area \\ desyastrid@gmail.com
}

\begin{abstract}
Managerial performance can be achieved by means of managers utilizing the ability to see and take advantage of opportunities, identify problems and select and apply the adaptation process appropriately. Through managerial performance in an organization can maintain the survival of an organization. The management accounting system is a formal system designed to provide information to managers. The research objective was to examine the effect of the management accounting system on managerial performance. The population in this study were managers and assistant managers at PT. Marajasa, amounting to 31 people and the sample is a saturated sample, namely 31 respondents. The data analysis technique used in this study used regression analysis to answer the research objectives. The results showed that the management accounting system had an effect on managerial performance
\end{abstract}

Keywords : management accounting systems, managerial performance

\section{PENDAHULUAN}

Peningkatan kinerja manajerial dapat dicapai dengan cara manajer memanfaatkan kemampuanuntuk melihat dan memanfaatkan peluang, mengidentifikasikan permasalahan dan menyeleksi serta mengimplementasikan proses adaptasi dengan tepat. Peningkatan kinerja manajerial manajer pada suatu organisasi akan meningkatkan kinerja organisasi yang pada akhirnya meningkatkan daya saing organisasi (Yuliantoro dkk, 2012).Mowday et al., menyatakan bawa peningkatan ataupun penurunan kinerja manajerialtergantung sejauhmana individulebih mementingkan diri sendiri atau bekerja demi kepentingan organisasinya yang merupakan aktualisasi dari tingkat komitmen yang dimiliknya(dalam Kartika, 2010).

Perusahaan yang maju dan berkembang dicapai dengan cara meningkatkan kinerja manajerial dengan maksimal dan baik (Andriyan, 2013).Kinerja manajerial yang baik dapat 
meningkatkan keuntungan suatu perusahaan dan menambah suatu kepercayaan investor kepada perusahaan (Yuliana, dkk 2012).

Di dalam suatu perusahaan, manajer membutuhkan sistem akuntansi manajemen (SAM)untuk melaksanakan fungsiperencanaan, pengendalian serta untukmengambil suatu keputusan. SAMyang dipakai dalam suatu perusahaan bertujuan yaitu:sebagai penyediaan informasi untuk menentukan harga pokok barang/jasa, sebagai informasi untukperencanaan, pengendalian, evaluasi serta perbaikan berkesinambungan serta untuk memberikaninformasi dalam pengambilan suatu keputusan. Manajemen membutuhkan suatu sistem evaluasi kinerjayang dapat membantu dalam mengevaluasi prestasi kerja perusahaan tersebut melalui kinerjamanajer dalam berbagai tingkat pusat pertanggungjawaban (Wirjono, 2013).Perusahaan mendesain SAMuntuk membantu perusahaan yangbersangkutan melalui para manajernya seperti perencanaan, pengorganisasian,pengarahan serta pengambilan keputusan (Lempas,2014).

Dengan kinerja manajerial pada suatu organisasi dapat mempertahankan kelangsungan hidup organisasi/perusahaan. SAMmerupakan suatu sistem formal yang dirancang untuk menyediakan informasi bagi manajer (Landre, 2016).SAMdapat mengarahkan ke suatu mekanisme yang mendukungstruktur organisasi/perusahaan (Watson, 1998 dalam Widodo dan Windi, 2011).

Berdasarkan uraian di atas maka dapat diketahui bahwa dalam mengelola perusahaan, kemampuan manajer merupakan barometer bagi pertumbuhan suatu organisasi/perusahaan. Penggunaan suatu teknologi informasi adalah salah satu cara untuk memudahkan pengelolaan suatu perusahaan. Manajer dikatakan memiliki suatu prestasi serta kinerja yang baikjika telah banyak menghasilkan laba untuk perusahaan, sehingga melalui uraian-uraian di atas, maka dianggap perlu untuk dilakukan penelitian yang lebih mendalam dengan judul "Pengaruh Sistem Akuntansi Manajemen Terhadap Kinerja Manajerial"

\section{KAJIAN LITERATUR}

\section{Kinerja Manajerial}

Kinerja manajerial diartikan sebagaisejauhmana manajer melaksanakan suatu fungsi manajemen (Mahoney et. al, 1963 dalam Hafitz, 2010). Kinerja manajerial merupakan kinerja anggota organisasi dalam suatu kegiatan-kegiatan manajerial yaitu perencanaan, 
investigasi, pengkoordinasian, pengaturan staf, negosiasi, perwakilan serta kinerja keseluruhan (Juniarti dan Evelin, 2013).

\section{Sistem Akuntansi Manajemen (SAM)}

SAM adalah suatu sistem yang mengumpulkan data-data operasional danfinansial serta memprosesnya kemudian menyimpannya dan melaporkannya kepada pengguna, yaitu kepada parapekerja, manajer dan eksekutif (Marina,2014).SAMdilihat sebagai suatu sistem yang memberikan suatu informasi benchmarkingserta monitoring dari informasi internal dan historissecara tradisional yang dihasilkan dari SAM. SAM merupakan suatu sistem formal yang dirancang sebagai penyediaan informasi bagi manajer (Ayu,2014)

Pendapat lain menyatakan bahwa SAMmerupakan suatusistem informasi yang menghasilkan outputdengan menggunakan inputserta berbagaiproses yang diperlukan untuk memenuhi tujuan manajemen. Proses merupakan inti SAM dan dipergunakan untuk mengubah input menjadi outputdalam pemenuhan tugassistem (Hansen \& Mowen, 2004).

\section{METODE}

Penelitian ini merupakan penelitian asosiatif kuantitatif. Sugiyono (2012) menyatakan penelitian asosiatif adalah penelitian yang memiliki tujuan untuk mengetahui hubungan antar dua variabel atau lebih. Penelitian ini akan dibangun suatu teori yang bertujuan untuk menjelaskan, meramalkan serta mengontrol gejala yang dilakukan di PT. Marajasa. Populasi penelitian adalah manajer serta asisten manajer pada PT. Marajasa sebanyak 31 orang dan sampel merupakan sampel jenuh yaitu 31 responden. Teknik analisa data dalam penelitian menggunakan analisis regresi untuk menjawab tujuan penelitian yang dirumuskan dalam persamaan : $\mathrm{Y}=\mathrm{a}+\beta \mathrm{X}$.

\section{HASIL PENELITIAN DAN PEMBAHASAN}

\section{HASIL PENELITIAN}

\section{a. Hasil Uji Asumsi Klasik}

\section{Uji Normalitas}

Model regresi yang dapat dipakaiapabila data yang diperoleh berdistribusi normal atau mendekati normal denga ketentuan nilai $\mathrm{p}>0,05$. Hasil uji normalitas diperoleh variabel sistem akuntansi manajemen dengan nilaiAsymp. Sig. (2-tailed) $=0,341>0,05$. 


\section{Uji Multikolinieritas}

Model regresi yang dapat dipakai jika tidak terjadi multikolinieritas dengan nilai Tolerance $>0,10$ atau sama dengan nilai VIF < 10. Hasil uji multikolinieritas diperoleh nilai VIF $=1,080<10$ sehingga dapat dinyatakan model regresi tidak terjadi multikolinieritas.

\section{Uji Heteroskedastisitas}

Model regresi yang dapat dipakai jika tidak terjadi heteroskesdasitas.Hasil uji heteroskedastisitas menunjukkan bahwa titik-titik tidak menunjukkan pola tertentu sehingga model regresi dinyatakan tidak terjadi heteroskedastisitas.

\section{b. Hasil Analisis Regresi}

Model regresi berganda yang dapat dipakai berfungsi untuk memprediksi besarnya variabel dependen dengan menggunakan data dari variabel independen yang sudah diketahui besarannya. Hasil uji statistik diperoleh hasil sebagai berikut:

\section{Tabel 1 Analisis Regresi}

Coefficients $^{\mathrm{a}}$

\begin{tabular}{|c|c|c|c|c|c|}
\hline \multirow[b]{2}{*}{ Model } & \multicolumn{2}{|c|}{$\begin{array}{c}\text { Unstandardized } \\
\text { Coefficients }\end{array}$} & \multirow{2}{*}{ 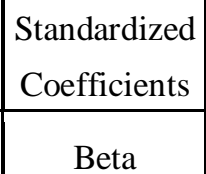 } & \multirow[b]{2}{*}{$\mathrm{t}$} & \multirow[b]{2}{*}{ Sig. } \\
\hline & B & Std. Error & & & \\
\hline $1 \quad$ (Constant) & 8.168 & 4.922 & & 1.659 & .108 \\
\hline Sistem Akuntansi Manajemen & .485 & .173 & .435 & 2.808 & .009 \\
\hline
\end{tabular}

a. Dependent Variable: Kinerja Manajerial

Berdasarkan tabel di atas diperoleh bahwa persamaan regresi :Y $=8,168+$ 0,485X. Berdasarkan persamaan regresi tersebut dapat dijelaskan bahwa nilai konstanta $=8,168$ dan koefisien regresi sistem akuntansi manajemen $\beta=0,485$.

\section{c. Hasil Uji Hipotesis}

Variabel sistem akuntansi manajemen $(\mathrm{X})$ diperoleh nilai thitung $=2,808$ dengan $\alpha=$ $0,05, \mathrm{df}=\mathrm{n}-\mathrm{k}=31-2=29$ sehingga $\mathrm{t}_{\text {tabel }}=2,045$ yang menunjukkan $t_{\text {hitung }}>\mathrm{t}_{\text {tabel }}$ sehingga Ha diterima dan H0 ditolak yang memiliki arti bahwa sistem akuntansi manajemen berpengaruh terhadap kinerja manajerial.

\section{d. Hasil Uji Kofisien Determinasi}


Koefisien determinasi digunakan untuk mengetahui besarnya pengaruhvariabel $\mathrm{X}$ terhadap Y. Hasil uji koefisien determinasi diperoleh sebagai berikut :

Tabel 2 Hasil Uji Koefisien Determinasi

\begin{tabular}{|l|r|r|r|r|}
\hline & & & \multicolumn{1}{|c|}{ Model Summary } \\
Model & $\mathrm{R}$ & R Square & \multicolumn{1}{c|}{$\begin{array}{c}\text { Adjusted R } \\
\text { Square }\end{array}$} & $\begin{array}{c}\text { Std. Error of the } \\
\text { Estimate }\end{array}$ \\
\hline 1 & $.632^{\mathrm{a}}$ & .400 & .357 & 6.347 \\
\hline
\end{tabular}

a. Predictors: (Constant), Desentralisasi, Sistem Akuntansi Manajemen

b. Dependent Variable: Kinerja Manajerial

Berdasarkan tabel di atas dapat diketahui bahwa nilai $\mathrm{R}=0,632$ sehingga berdasarkan rumus koefisien determinasi diperoleh hasil : $\mathrm{KD}=r^{2} \mathrm{x} 100 \%=$ $(0,632)^{2} \times 100 \%=40 \%$ yang artinya kinerja manajerial dapat dijelaskan oleh sistem akuntansi manajemen sebesar $40 \%$ dan sisanya sebesar $60 \%$ dijelaskan oleh faktor lain yang tidak diteliti.

\section{PEMBAHASAN}

\section{Pengaruh Sistem Akuntansi Manajemen Terhadap Kinerja Manajerial}

Dari hasil pengolahan data diketahui sistem akuntansi manajemen dengan nilai $t_{\text {hitung }}$ $=2,808>\mathrm{t}_{\text {tabel }}=2,045 \mathrm{yang}$ menunjukkan sistem akuntansi manajemen berpengaruh terhadap kinerja manajerial. Berpengaruhnya sistem akuntansi manajemen terhadap kinerja manajerial dapat diketahui dari beberapa pendapat yang diantaranya karyawan setuju ataupun sangat setuju menyatakan perusahaan memiliki data operasional dan finansial, perusahaan memiliki informasi yang dibutuhkan tentang kemungkinan kejadian dimasa yang akan datang serta setiap keputusan yang diambil dapat diketahui melalui sistem informasi. Namun disisi lain juga diketahui bahwa terdapat beberapa karyawan juga menyatakan tidak setuju perusahaan memiliki data operasional dan finansial, perusahaan 
memiliki informasi yang dibutuhkan tentang kemungkinan kejadian dimasa yang akan datang serta setiap keputusan yang diambil dapat diketahui melalui sistem informasi.

Adanya perbedaan pendapat dari karyawan tersebut menunjukkan bahwa bila sistem akuntansi manajemen diterapkan dengan baik di suatu perusahaan maka akan menghasilkan kinerja manajerial yang baik dan dari perbedaan pendapat karyawan tersebut menunjukkan bahwa PT. Marajasabelum sepenuhnya menerapkan sistem akuntansi manajemen sehingga mempengaruhi kinerja manajerial yang pada akhirnya mempengaruhi pendapatan perusahaan. Hal ini terlihat dari data pendapatan perusahaan dalam tiga tahun menunjukkan penurunan.

\section{KESIMPULAN}

Berdasarkan hasil pengolahan serta analisis data dapat disimpulkan bahwa sistem akuntansi manajemen berpengaruh terhadap kinerja manajerial. Hasil penelitian ini sesuai dengan pendapat Tiffin dan Mccormick (1975) yang dikutip oleh Sukrisna dan Trisnowati (2013) bahwafaktor-faktor yang dapat mempengaruhi kinerja diantaranya adalah faktor situasional, yaitu faktor yang meliputi sosial dan organisasi, meliputikebijakan organisasi seperti pemanfaatan informasi sistem akuntansi manajemen serta pendapat Marina (2014) yang menyatakan bahwa SAMmerupakansuatu sistem yang mengumpulkan data-data operasional danfinansial serta memprosesnya kemudian menyimpannya dan melaporkannya kepada pengguna, yaitu kepada parapekerja, manajer dan eksekutif.

\section{REFERENSI}

Andriyan,Pambudi. 2013.Pengaruh Penerapan Sistem Pengendalian Manajemen. Pada Pusat Pendapatan Dan Pusat Biaya Terhadap Kinerja Manajerial.

Ayu,Gusti.2014.Pengaruh Karakteristik Informasi Sistem Akuntansi Manajemen TerhadapKinerja Manajerial Studi Empiris pada PT Bank Perkreditan Rakyat di KabupatenTanah Datar. Journal of Economic and Economic Education Vol.3 No.1

Hafitz, 2010.Penatausahaan dan Akuntansi Keuangan Daerah. Jakarta. Salemba Empat

Hansen dan Mowen, 2004.Manajemen Biaya, Edisi Bahasa Indonesia. Jakarta: Salemba Empat

Juniarti \& Evelin.2013.Hubungan Karakteristik Informasi yang Dihasilkan oleh Sistem Informasi Akuntansi Manajemen terhadap Kinerja Manajerialpada Perusahaanperusahaan Manufaktur di Jawa Timur. Jurnal Riset Akuntansi Indonesia 
Landre, Ayu Krisma.2016.Pengaruh Desentralisasi, Kualitas Informasi Akuntansi Manajemen Dan Ketidakpastian Lingkungan Terhadap Kinerja Manajerial (Survei pada PT Pos Indonesia (Persero) di Kota Bandung). Bandung: Skripsi Fakultas Ekonomi Unpas.

Lempas, Yuwinda dkk. 2014. Desentralisasi dan Sistem Akuntansi Manajemen Terhadap Kinerja ManajerPada PT. SInar Galesong Prima Manado. Jurnal EMBA,Vol. 2 No. 1 Hal 431-440

Marina, Anna.2014.Pengaruh Sistem Akuntansi Manajemen Terhadap Kinerja Manajerialdengan Ketidakpastian Lingkungan dan Desentralisasi Sebagai Variabel Moderating.JAI 5(2), Juli 2014.

Sugiyono, 2012.Metode Penelitian Bisnis. Bandung : Alfabeta

Sukrisna dan Trisnowati, 2013.Akuntansi Perpajakan. Jakarta: Salemba. Empat

Wirjono, Raino Endang2013.Hubungan Antara Sistem Akuntansi Manajemen danKetidakpastian Lingkungan yang dirasakan terhadap Kinerja Manajerial. JurnalVol. 8 No.1 Januari 2013

Yuliantoro, dkk 2012.Pengaruh Komitmen Organisasi Terhadap Hubungan Antara Partisipasi Anggaran Dan Kinerja Manajerial. Jurnal Akuntansi Keuangan dan Bisnis Vol.5, Desember 2012, 01-11

Yuliana, Nadirsyah\& Usman Bakar. 2012.Pengaruh penerapan TQM, terhadap kinerja manajerial, dengan budaya organisasi, sistem pengukuran kinerja, dan sistem pengukuran kinerja sebagai variabel moderating. Banda Aceh : Program Pascasarjana Universitas Syiah Kuala

Widodo dan Windi, 2011. Pengaruh Desentralisasi Dan Karakteristik Informasi Sistem Akuntansi Manajemen Terhadap Kinerja Manajerial Padat PT (Persero) Pelabuhan Indonesia III Cabang Tanjung Perak. Seminar Nasional Ilmu Ekonomi TerapanFakultas Ekonomi UNIMUS. 